\title{
STUDIES ON THE METABOLISM OF PLASMA PROTEINS IN THE NEPHROTIC SYNDROME. I. ALBUMIN, $\gamma$-GLOBULIN AND IRON-BINDING GLOBULIN ${ }^{1}$
}

\author{
By DAVID GITLIN, CHARLES A. JANEWAY, AND LEE E. FARR
}

\author{
(From the Department of Pediatrics, Harvard Medical School and the Children's Medical \\ Center, Boston, Mass., and the Medical Department, Brookhaven National \\ Laboratory, Upton, $N . Y$.)
}

(Submitted for publication May 27, 1955; accepted September 7, 1955)

Although there is unanimity of opinion that the nephrotic syndrome is characterized by proteinuria, hypoproteinemia, edema and hyperlipemia, there is considerably less agreement as to the mechanisms which result in these findings. It is now generally held that the proteinuria found in this disease is related directly to the renal lesion (1) and is not attributable to the excretion of abnormal plasma proteins (2). The cause of the severe hypoproteinemia in this disease, however, is a more controversial subject. The association of proteinuria and hypoproteinemia as cause and effect has been postulated by a number of investigators (1-4) and the occasionally prodigious amounts of plasma protein excreted by children with the nephrotic syndrome makes the relationship attractive. This concept, however, is not universally accepted (5), and it has long been suggested that the degree of hypoproteinemia may not depend upon the severity of proteinuria alone (6).

This study was undertaken in an effort to determine the factors responsible for hypoproteinemia in children with the nephrotic syndrome. Since the concentration of a given plasma protein in the circulation is dependent upon its rate of synthesis, its rate of loss from the body whether by catabolism or excretion or both, and its distribution within the body, an attempt was made to estimate these quantities for albumin, $\gamma$-globulin and iron-binding globulin during various stages of this disease.

\section{METHODS}

Patients: Six children with the nephrotic syndrome were selected for study. The pertinent medical data are summarized in Table $I$. It will be noted that three

1 Supported by grants from the National Institutes of Health, U. S. Public Health Service (A-251), from the Playtex Park Research Institute, and from the U. S. Atomic Energy Commission. recognizable stages of the disease were represented: 1) Almost complete remission in Group I (one child with residual proteinuria, but without hypoproteinemia, edema, ascites or hyperlipemia) ; 2) partial remission in Group II (two children with proteinuria, hypoproteinemia and hyperlipemia but only minimal intermittent local edema and no recognizable ascites); 3) full-blown disease in Group III (three children with proteinuria, hypoproteinemia, anasarca, ascites and hyperlipemia).

These children were fully ambulatory throughout the study, which took place during the summer months. No evidence of infection was observed in these children during the course of the investigation.

Method of study: Each of the six patients was first given radio-iodinated albumin and, when the radiation in urine and plasma had fallen to background level, radioiodinated $\gamma$-globulin was injected. After the latter, when background level was again attained in urine and plasma, three of the children were given radio-iodinated iron-binding globulin. The proteins were injected intravenously; the specific activities of these protein preparations were such that no more than $1 \mathrm{mg}$. of iodoalbumin, $0.5 \mathrm{mg}$. of iodinated $\gamma$-globulin or $0.2 \mathrm{mg}$. of iodinated iron-binding globulin was injected per patient. The maximum radiation employed in any given injection was 1.5 microcuries per kilogram body weight. Beginning 24 hours prior to the administration of radio-iodinated albumin and continuing throughout the period of study, the children were given 10 drops of Lugol's solution three times a day.

Radio-iodinated plasma proteins: Each lot of radioiodinated plasma protein used in this study was tested for free and loosely bound radio-iodide by dialysis, by precipitation of protein in 10 per cent trichloracetic acid in the presence of suitable carrier protein, and by precipitation of specific protein in the zone of antibody excess with specific rabbit antiserum (7). Control studies indicated that unbound or loosely bound radio-iodide could be completely recovered in the dialysate or supernatants of these procedures. The three methods gave similar results.

One preparation of iodinated human plasma albumin obtained from Abbott Laboratories, No. 806-169-50, was considered satisfactory and was used in each of the six patients; less than 2 per cent of the radio-iodide in this preparation was unbound according to the above methods. Using the quantitative precipitin reaction, the iodoalbumin 
TABLE I

Clinical and laboratory data during study period

\begin{tabular}{|c|c|c|c|c|c|c|c|c|c|c|}
\hline Patient & $\underset{\text { (yrs.) }}{\text { Age }}$ & $\begin{array}{c}\text { Weight* } \\
\left(K_{g}\right)\end{array}$ & $\begin{array}{c}\text { Height } \\
\text { (cm.) }\end{array}$ & $\begin{array}{c}\text { Urea } \\
\text { nitro- } \\
\text { gen } \\
(\boldsymbol{m g} . \%)\end{array}$ & $\begin{array}{c}\begin{array}{c}\text { Serum } \\
\text { cholesterol } \\
(m g . \%)\end{array} \\
\text { (mg. \% }\end{array}$ & $\begin{array}{c}\text { Red blood } \\
\text { cells (mill./ } \\
\text { c. mm.) }\end{array}$ & $\begin{array}{c}\text { Time } \\
\text { since } \\
\text { onset } \\
\text { of } \\
\text { illness } \\
\text { (mos.) }\end{array}$ & Ascites & Edema & $\begin{array}{c}\text { Gross } \\
\text { proteinuria } \\
(\mathrm{gm} . / 24 \mathrm{hr} .)\end{array}$ \\
\hline $\begin{array}{l}\text { Group I } \\
\text { R. S. B. }\end{array}$ & $5-7 / 12$ & $19.4-19.8$ & 105 & 30 & $243-275$ & $3.81-4.96$ & $44 \dagger$ & \multicolumn{2}{|c|}{$\begin{array}{l}0 \\
\text { Disappeared } \\
12 \text { mos. ago }\end{array}$} & $1.0-1.6$ \\
\hline $\begin{array}{l}\text { Group } I I \\
\text { A. B. }\end{array}$ & $6-7 / 12$ & $24.9-26.0$ & 122 & 11 & $725-752$ & $4.97-5.56$ & 44 & \multicolumn{2}{|c|}{$\begin{array}{l}0 \quad \stackrel{ \pm}{ \pm} \quad(\text { ankles) } \\
\text { Disappeared } \\
6 \text { mos. ago }\end{array}$} & $1.6-2.5$ \\
\hline E. T. & $6-6 / 12$ & $23.4-23.5$ & 119 & 34 & $1218-1318$ & $2.91-3.33$ & 56 & $\begin{array}{l}0 \\
\text { Disa } \\
10 \mathrm{n}\end{array}$ & $\begin{array}{l}\stackrel{ \pm}{ \pm} \\
\text { (orbital) } \\
\text { ared } \\
\text { ago }\end{array}$ & $9.2-9.6$ \\
\hline $\begin{array}{l}\text { Group III } \\
\text { K. S. } \\
\text { S. L. } \\
\text { D. W. }\end{array}$ & $\begin{array}{l}3-4 / 12 \\
6-5 / 12 \\
3-4 / 12\end{array}$ & $\begin{array}{l}19.3-22.0 \\
32.4-33.6 \\
16.2-16.3\end{array}$ & $\begin{array}{r}101 \\
118 \\
95\end{array}$ & $\begin{array}{l}28 \\
20 \\
13\end{array}$ & $\begin{array}{c}1302-1443 \\
1260-1521 \\
703-817\end{array}$ & $\begin{array}{l}3.80-4.71 \\
3.07-4.57 \\
4.43-5.01\end{array}$ & $\begin{array}{l}13 \\
11 \\
18 \ddagger\end{array}$ & $\begin{array}{l}+++- \\
+++- \\
+++-\end{array}$ & $\begin{array}{c}++++ \\
+++ \\
++\end{array}$ & $\begin{array}{l}2.4-4.5 \\
9.0-9.2 \\
2.7-4.9\end{array}$ \\
\hline
\end{tabular}

* At the beginning and at end of study.

$\dagger$ At onset, had a course of ACTH without apparent effect.

$\ddagger$ Oral cortisone had been given without effect on two occasions, the last time 12 mos. before this study.

could not be distinguished immunochemically from normal human plasma albumin (2).

Radio-iodinated human $\boldsymbol{\gamma}$-globulin was prepared with human $\gamma$-globulin, Harvard No. 159-4, isolated from pooled plasma by low temperature-ethanol fractionation (8). The human iron-binding globulin used, Harvard No. 194-2x, was crystallized from Fraction IV-7 (9) and has been immunochemically characterized (10). $I^{121}$ was obtained as carrier-free $\mathrm{NaI}$ in sodium bisulfite; the iodide and bisulfite were oxidized with nitrous acid and the solution neutralized with sodium hydroxide (11). A solution of $0.94 \times 10^{-3} \mathrm{M} \mathrm{I}_{2}$ in $1.33 \times 10^{-3} \mathrm{M} \mathrm{KI}$ was added to the $\mathrm{I}^{181}$ solution and this mixture was then added to a solution of the protein in $0.2 \mathrm{M} \mathrm{NaHCO}-\mathrm{Na}_{2} \mathrm{CO}_{3}$ buffer, $\mathrm{pH} 9.5$ (12). The iodinated iron-binding globulin was calculated to have an average of 3 atoms of iodine per molecule and the iodinated $\boldsymbol{\gamma}$-globulin was calculated to have an average of 1.5 atoms of iodine per molecule. The proteins were dialyzed against several daily changes of $0.15 \mathrm{M} \mathrm{KI}$ and then against several daily changes of 0.15 $\mathrm{M} \mathrm{NaCl}$. Precipitation of protein with trichloracetic acid or with specific antibodies revealed that less than 2 per cent of the total radioactivity of each preparation was free or loosely bound. The iodoproteins could not be distinguished immunochemically from the native analogues used in their preparation (2).

Preparation of specimens for analysis: Urine collection periods varied from several minutes at the beginning of each protein study to several days at the end of each study. Two or $3.0-\mathrm{ml}$. aliquots of urine were placed in screw cap vials for counting; for routine estimation of nonprotein radio-iodide, an additional aliquot of urine was mixed with an equal volume of 20 per cent trichloracetic acid, allowed to stand at $1^{\circ} \mathrm{C}$ for 6 to 24 hours, centrifuged, and aliquots of the clear supernatant placed in vials. Trichloracetic acid precipitation and immunochemical precipitation gave almost identical results for nonprotein radio-iodide. The difference between the total activity of the urine sample and that of the nonprotein radio-iodide in that sample was taken as the activity due to intact radio-iodinated plasma protein.

After venipuncture, blood was allowed to clot and the serum separated for counting. Serum rather than plasma was used, since the same specimen that was assayed for radioactivity could then be used for immunochemical estimations.

In this report, serum and plasma concentrations of the plasma proteins studied have been considered equivalent. Periodically, aliquots of blood were mixed with sodium oxalate for estimation of hematocrit.

Edema fluid was obtained near the termination of each plasma protein disappearance study in the three patients of Group III. A No. 19 spinal needle, 1.5 inches long and with stylet in place, was inserted into the subcutaneous tissues of the leg in a dependent position; upon removing the stylet, fluid without any traces of red cells flowed freely directly into a centrifuge tube. Unfortunately, serial sampling of edema and ascitic fluids was not done.

Assay of radioactivity: A well-type, sodium iodide crystal scintillation counter was employed which gave $9.4 \times 10^{5}$ counts per minute per microcurie of $\mathrm{I}^{131}$. All 
specimens in 2.0 or $3.0-\mathrm{ml}$. aliquots were placed in 15 by $45 \mathrm{~mm}$. screw cap vials for counting. Radioactive standards were prepared for each iodinated plasma protein studied for each individual patient. Using the same syringe and needle that had been used for the injection and an aliquot of the same solution of radioactive protein used in that instance, a dilution of the injected material was prepared and aliquots of 2.0 and $3.0 \mathrm{ml}$. were placed in vials as above; these served as standards for the appropriate volume of unknown, thus avoiding problems of decay and geometry.

Immunochemical methods: Rabbit antisera vs. crystallized human serum albumin, human $\boldsymbol{\gamma}$-globulin and crystallized human iron-binding globulin were prepared as previously described $(2,10)$. The spectrophotometric method was used for analysis of specific precipitates (7). All specific protein values in this report are based on immunochemical estimations.

Determination of plasma volume: The plasma volume in each instance was taken as the total activity injected less the total amount of activity found in the urine in $\mathbf{1 2}$ to 16 minutes divided by the activity in the serum obtained from venous blood taken in 12 to 16 minutes. The total amount of activity in the urine at the end of this period was always less than 0.5 per cent of the amount injected, even in the patients of Group III, and although the plasma volumes were not corrected for catabolism or extravascular diffusion of iodoprotein dur- ing this period of time, these corrections were of similar order of magnitude.

Definitions of terms: For the sake of clarity, the following definitions are given:

The body pool or total exchangeable pool of a given plasma protein is the total amount of that protein in the body which is available for exchange with additional or newly synthesized molecules of that specific protein.

The turnover half-time of a plasma protein is the amount of time required for half of the body pool of that protein to be lost to the body through all channels of loss. The turnover half-time due to catabolism (or urinary loss) is the time required for half of the body pool of the protein in question to be lost through catabolism (or urinary loss). The fractional rate of catabolism (or urinary loss) is that fraction of the body pool of a given protein that is catabolized (or excreted) per unit time. Turnover-time or half-life are expressions that are frequently used instead of turnover half-time; the fractional rates of catabolism and urinary loss are turnover rates.

The rate of synthesis, catabolism, or urinary loss is the amount of protein that is synthesized, catabolized, or lost in the urine per unit time, respectively.

The volume of distribution of a protein is taken as the volume that a protein would occupy if the total exchangeable pool of the protein had a uniform concentration equal to the plasma concentration of that protein. It is to be definitely understood that this term has no ana-

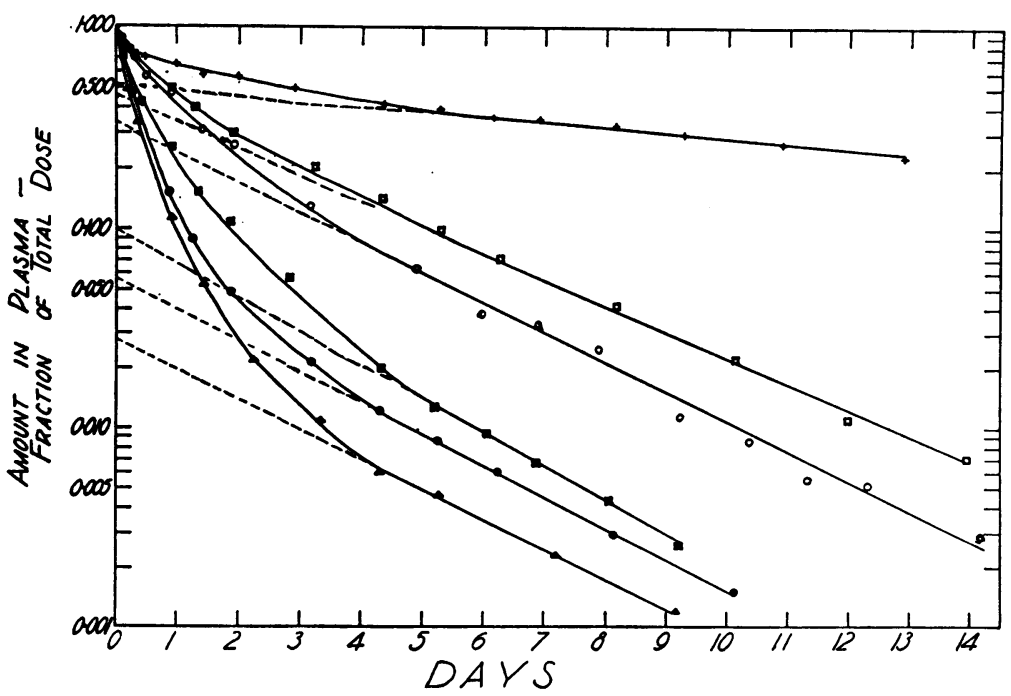

Fig. 1. The Disappearance of Iodinated Plasma Albumin from the Circulation after Intravenous InJection

In this figure and in all subsequent figures, the following symbols apply:

$$
\begin{aligned}
& + \text { R. S. B. } \\
& \square \text { A. B. } \\
& \text { O E. T. } \\
& \text { K. S. } \\
& \text { S. L. } \\
& \text { D. W. }
\end{aligned}
$$


TABLE II

Rates of urinary loss, catabolism, and synthesis of albumin, $\gamma$-globulin and iron-binding globulin

\begin{tabular}{|c|c|c|c|c|c|c|c|c|}
\hline \multirow[b]{2}{*}{ Patient } & \multirow{2}{*}{$\begin{array}{c}\text { Serum } \\
\text { concentration } \\
(\mathrm{gm} . \%)\end{array}$} & \multirow{2}{*}{$\begin{array}{c}\text { Plasma } \\
\text { volume } \\
(m l .)\end{array}$} & \multirow{2}{*}{$\begin{array}{c}\text { Renal } \\
\text { clearance } \\
\text { of specific } \\
\text { protein } \\
(\text { ml. } / \text { min. })\end{array}$} & \multicolumn{2}{|c|}{$\begin{array}{c}\text { Estimated cumulative } \\
\text { urinary losses }\end{array}$} & \multicolumn{3}{|c|}{ Rates } \\
\hline & & & & $\begin{array}{l}\text { Iodinated } \\
\text { protein* }\end{array}$ & $\begin{array}{c}\text { Nonprotein } \\
\text { iodidet }\end{array}$ & $\begin{array}{c}\text { Urinary losst } \\
(\mathrm{gm.} / \text { day })\end{array}$ & $\underset{(\mathrm{gm} . / \text { day })}{\text { Catabolism }}$ & $\begin{array}{c}\text { Synthesis\| } \\
\text { (gm./day) }\end{array}$ \\
\hline \multicolumn{9}{|l|}{ A: Albumin } \\
\hline I-R. S. B. & 4.33 & 1405 & 0.015 & 0.15 & 0.85 & 0.95 & 5.38 & 6.33 \\
\hline II $\left\{\begin{array}{l}\text { A. B. } \\
\text { E. T. }\end{array}\right.$ & $\begin{array}{l}0.86 \\
0.77\end{array}$ & $\begin{array}{l}1156 \\
1283\end{array}$ & $\begin{array}{l}0.166 \\
0.472\end{array}$ & $\begin{array}{l}0.27 \\
0.75\end{array}$ & $\begin{array}{l}0.73 \\
0.25\end{array}$ & $\begin{array}{l}2.06 \\
5.22\end{array}$ & $\begin{array}{l}5.57 \\
1.74\end{array}$ & $\begin{array}{l}7.63 \\
6.96\end{array}$ \\
\hline III $\left\{\begin{array}{l}\text { K. S. } \\
\text { S. L. } \\
\text { D. W. }\end{array}\right.$ & $\begin{array}{l}0.58 \\
0.40 \\
0.61\end{array}$ & $\begin{array}{r}749 \\
1001 \\
701\end{array}$ & $\begin{array}{l}0.236 \\
0.794 \\
0.246\end{array}$ & $\begin{array}{l}0.32 \\
0.61 \\
0.27\end{array}$ & $\begin{array}{l}0.68 \\
0.39 \\
0.73\end{array}$ & $\begin{array}{l}1.96 \\
4.61 \\
2.15\end{array}$ & $\begin{array}{l}4.17 \\
2.95 \\
5.81\end{array}$ & $\begin{array}{l}6.13 \\
7.56 \\
7.96\end{array}$ \\
\hline \multicolumn{2}{|l|}{ B: $\gamma$-Globulin } & 1236 & 0.004 & 0.07 & 0.93 & 0.035 & & 0.500 \\
\hline II $\left\{\begin{array}{l}\text { A. B. } \\
\text { E. T. }\end{array}\right.$ & $\begin{array}{l}0.390 \\
0.219\end{array}$ & $\begin{array}{l}1152 \\
1388\end{array}$ & $\begin{array}{l}0.078 \\
0.148\end{array}$ & $\begin{array}{l}0.09 \\
0.69\end{array}$ & $\begin{array}{l}0.91 \\
0.31\end{array}$ & $\begin{array}{l}0.112 \\
0.466\end{array}$ & $\begin{array}{l}1.13 \\
0.209\end{array}$ & $\begin{array}{l}1.24 \\
0.675\end{array}$ \\
\hline III $\left\{\begin{array}{l}\text { K. S. } \\
\text { S. L. } \\
\text { D. W. }\end{array}\right.$ & $\begin{array}{l}0.186 \\
0.193 \\
0.189\end{array}$ & $\begin{array}{r}856 \\
1008 \\
733\end{array}$ & $\begin{array}{l}0.076 \\
0.134 \\
0.013\end{array}$ & $\begin{array}{l}0.23 \\
0.52 \\
0.07\end{array}$ & $\begin{array}{l}0.77 \\
0.48 \\
0.93\end{array}$ & $\begin{array}{l}0.110 \\
0.372 \\
0.035\end{array}$ & $\begin{array}{l}0.368 \\
0.343 \\
0.465\end{array}$ & $\begin{array}{l}0.478 \\
0.715 \\
0.500\end{array}$ \\
\hline $\begin{array}{c}\text { C: Iron-binding } 8 \\
\text { II }\left\{\begin{array}{l}\text { A. B. } \\
\text { E. T. }\end{array}\right.\end{array}$ & $\begin{array}{l}0.0280 \\
0.0285\end{array}$ & $\begin{array}{l}1388 \\
1374\end{array}$ & $\begin{array}{l}0.117 \\
0.372\end{array}$ & $\begin{array}{l}0.20 \\
0.57\end{array}$ & $\begin{array}{l}0.80 \\
0.43\end{array}$ & $\begin{array}{l}0.0472 \\
0.153\end{array}$ & $\begin{array}{l}0.189 \\
0.115\end{array}$ & $\begin{array}{l}0.236 \\
0.268\end{array}$ \\
\hline III-S. L. & 0.0145 & 1191 & 0.360 & 0.48 & 0.52 & 0.0752 & 0.0816 & 0.157 \\
\hline
\end{tabular}

* As fraction of total dose: $A^{*} / A_{*}^{*}$ in Equation (1).

$\dagger$ As fraction of total dose: $1-A^{*} / A_{*}^{*}$.

$\$ A_{0}$ in Equation (1).

$\$ A_{0}$ in Equation (2).

$\mathrm{A}_{\mathrm{s}}$ in Equation (1).

tomical implications and does not indicate the extent of distribution of the protein in the body; knowing the plasma concentration of a protein, the volume of distribution indicates, among other things, the size of the body pool.

\section{RESULTS}

\section{Studies with Radio-iodinated Human Plasma Albumin}

A. The disappearance of iodinated plasma albumin from the circulation: The disappearance of radio-iodinated albumin from the plasma of the six children is shown in Figure 1; it should be noted that the ordinates are logarithmic. Simple graphic analysis of these curves resulted in the biological half-life values for total body albumin that are indicated in Table IIIA. The half-life of albumin in the patient of Group I would appear to be within normal limits $(13,14)$; the half-life of albumin in the patients of Groups II and III would appear to be greatly diminished.

Upon extrapolation of the exponential portions of the disappearance curves to zero time, at first glance it would appear that the children with anasarca and ascites had abnormally large volumes of distribution. Even correcting the curves of Figure 1 by the method of Berson, Yalow, Schreiber, and Post (14), the apparent volume of distribution in the latter patients remained 7 to 10 times the plasma volume. Calculation of the amount of albumin ${ }^{2}$ actually present in edema

2 For example, patient S. L.: Weight: $32 \mathrm{Kg}$. Height : $118 \mathrm{~cm}$. Estimated edema-free weight: $20 \mathrm{Kg}$.

Hence, excess fluid $=32 \mathrm{Kg} .-20 \mathrm{Kg} .=12 \mathrm{Kg}$. and of this, $3 \mathrm{Kg}$. was ascites. If the normal interstitial fluid space in humans is assumed to be roughly 20 per cent of the body weight, the normal amount of interstitial fluid in this patient in the edema-free state would be 20 per cent of $20 \mathrm{Kg}$. or $4 \mathrm{Kg}$. The total interstitial fluid in the edematous state less the amount of ascitic fluid would then be $(12 \mathrm{Kg} .-3 \mathrm{Kg}$. $)+4 \mathrm{Kg}$. $=13 \mathrm{Kg}$.; with an albumin concentration of $0.01 \mathrm{gm}$. per cent, this fluid would account for about $1.3 \mathrm{gm}$. of albumin. Three $\mathrm{Kg}$. of ascitic fluid with an albumin concentration of $0.02 \mathrm{gm}$. per cent (2) would represent $0.6 \mathrm{gm}$. albumin. The total extravascular-extracellular albumin would be $1.3 \mathrm{gm} .+$ $0.6 \mathrm{gm}$. or $1.9 \mathrm{gm}$. Since the plasma volume was 1001 $\mathrm{ml}$. and the albumin concentration in the plasma was $\mathbf{0 . 5 2}$ 
and ascitic fluids and plasma, however, indicated that most of the body albumin, as estimated from such volumes of distribution, cannot be accounted for in these spaces. This apparent discrepancy cannot easily be explained on the basis of albumin being bound to such structures as collagenous fibers, nor can the discrepancy satisfactorily be attributed to a "pool" of intracellular albumin (10). At no time in any of the patients was the plasma nonprotein radio-iodide more than 10 per cent of the total activity of the plasma sample, and hence the problem is not a result of counting nonprotein radio-iodide with radio-iodinated albumin.

gm. per cent, the total vascular albumin was $5.2 \mathrm{gm}$. Total body albumin in this patient, therefore, was $1.9 \mathrm{gm}$. $+5.2 \mathrm{gm}$. or $7.1 \mathrm{gm}$. The volume of distribution of albumin as estimated from the plasma disappearance curve after an attempt at correction (14) was $7100 \mathrm{ml}$; the body pool of albumin on this basis should have been

$$
7100 \mathrm{ml} . \times \frac{0.52 \mathrm{gm} . \text { albumin }}{100 \mathrm{ml} .}=36.9 \mathrm{gm} \text {. }
$$

Thus, if the latter were correct, $36.9 \mathrm{gm}$. $-7.1 \mathrm{gm}$. or $29.8 \mathrm{gm}$. of albumin cannot be accounted for.
Direct examination of the edema fluids obtained from the children in Group III, however, revealed that in the period of exponential decline of iodoalbumin in the plasma, the specific activity of albumin in the edema fluid, in counts per minute per gram of albumin, was roughly 30 times that of the plasma; of the radioactivity in the edema fluid, less than 10 per cent was due to nonprotein radio-iodide. Multiplying the specific activity of the albumin in edema fluid by the amount of endogenous albumin present in the extravascular fluids ${ }^{2}$ indicated that the total amount of radioactivity present extravascularly at the time of sampling the edema fluid was roughly 9 to 10 times that in the plasma.

Thus, it would appear that the large volume of distribution obtained in each of the patients of Group III represented the final volume of distribution of the iodoalbumin administered and not that of the body pool of endogenous albumin. Actually, this situation should be expected in a three- or more compartment open system such as

TABLE III

Turnover of total body albumin, $\gamma$-globulin and iron-binding globulin

\begin{tabular}{|c|c|c|c|c|c|c|c|c|}
\hline \multirow[b]{3}{*}{ Patients } & \multirow{3}{*}{$\begin{array}{c}\text { Specific protein } \\
\text { in vascular } \\
\text { compartment* } \\
\text { (gm.) }\end{array}$} & \multirow{3}{*}{$\begin{array}{c}\text { Estimated total } \\
\text { pool of specific } \\
\text { proteint }=\mathrm{T}_{\mathbf{A}} \\
(\mathrm{gm} .)\end{array}$} & \multirow{3}{*}{$\begin{array}{c}\text { From plasma } \\
\text { disappearance } \\
\text { (days) }\end{array}$} & \multicolumn{3}{|c|}{ Approximate half-time of turnover } & \multirow{2}{*}{\multicolumn{2}{|c|}{$\begin{array}{l}\text { Fractional rates } \\
\text { of turnover }\end{array}$}} \\
\hline & & & & \multirow{2}{*}{$\begin{array}{c}\text { From } \\
\text { Equation } \\
(4) \\
\text { tet } \\
(\text { days })\end{array}$} & \multirow{2}{*}{$\begin{array}{c}\text { Urinary } \\
\text { lossł } \\
t_{0} \frac{1}{7} \\
(\text { days })\end{array}$} & \multirow{2}{*}{$\begin{array}{c}\text { Catabolism } \ddagger \\
t_{0} \frac{1}{2} \\
(\text { days })\end{array}$} & & \\
\hline & & & & & & & $\begin{array}{c}\text { Urinary loss } \\
\text { (per day) }\end{array}$ & $\begin{array}{c}\text { Catabolism } \\
\text { (per day) }\end{array}$ \\
\hline \multicolumn{9}{|l|}{ A: Albumin } \\
\hline I-R. S. B. & 60.8 & 135.2 & 12.0 & 14.7 & 98.8 & 17.5 & 0.007 & 0.040 \\
\hline II $\left\{\begin{array}{l}\text { A. B. } \\
\text { E. T. }\end{array}\right.$ & $\begin{array}{l}9.94 \\
9.88\end{array}$ & $\begin{array}{l}22.1 \\
22.0\end{array}$ & $\begin{array}{l}2.3 \\
2.0\end{array}$ & $\begin{array}{l}2.0 \\
2.2\end{array}$ & $\begin{array}{l}7.5 \\
2.9\end{array}$ & $\begin{array}{l}2.8 \\
8.7\end{array}$ & $\begin{array}{l}0.093 \\
0.237\end{array}$ & $\begin{array}{l}0.252 \\
0.079\end{array}$ \\
\hline III $\left\{\begin{array}{l}\text { K. S. } \\
\text { S. L. } \\
\text { D. W. }\end{array}\right.$ & $\begin{array}{l}4.34 \\
4.00 \\
4.28\end{array}$ & $\begin{array}{l}9.6 \\
8.9 \\
9.5\end{array}$ & $\begin{array}{l}1.8 \\
2.1 \\
2.0\end{array}$ & $\begin{array}{l}1.1 \\
0.8 \\
0.8\end{array}$ & $\begin{array}{l}3.3 \\
1.4 \\
3.1\end{array}$ & $\begin{array}{l}1.7 \\
2.1 \\
1.1\end{array}$ & $\begin{array}{l}0.204 \\
0.518 \\
0.226\end{array}$ & $\begin{array}{l}0.434 \\
0.331 \\
0.612\end{array}$ \\
\hline \multicolumn{9}{|l|}{ B: $\gamma$-Globulin } \\
\hline I一R. S. B. & 7.55 & 16.8 & 22.0 & 23.3 & 33.3 & 25.1 & 0.002 & 0.028 \\
\hline II $\left\{\begin{array}{l}\text { A. B. } \\
\text { E. T. }\end{array}\right.$ & $\begin{array}{l}4.49 \\
3.04\end{array}$ & $\begin{array}{l}9.98 \\
6.76\end{array}$ & $\begin{array}{l}3.8 \\
3.7\end{array}$ & $\begin{array}{l}5.5 \\
6.9\end{array}$ & $\begin{array}{l}61.8 \\
10.1\end{array}$ & $\begin{array}{r}6.1 \\
22.4\end{array}$ & $\begin{array}{l}0.011 \\
0.069\end{array}$ & $\begin{array}{l}0.113 \\
0.031\end{array}$ \\
\hline III $\left\{\begin{array}{l}\text { K. S. } \\
\text { S. L. } \\
\text { D. W. }\end{array}\right.$ & $\begin{array}{l}1.59 \\
1.95 \\
1.39\end{array}$ & $\begin{array}{l}3.54 \\
4.32 \\
3.08\end{array}$ & $\begin{array}{l}3.4 \\
4.1 \\
3.3\end{array}$ & $\begin{array}{l}5.1 \\
4.1 \\
4.5\end{array}$ & $\begin{array}{r}22.3 \\
8.0 \\
61.1\end{array}$ & $\begin{array}{l}6.6 \\
8.7 \\
4.6\end{array}$ & $\begin{array}{l}0.031 \\
0.086 \\
0.011\end{array}$ & $\begin{array}{l}0.104 \\
0.079 \\
0.151\end{array}$ \\
\hline \multicolumn{9}{|c|}{ C: Iron-binding globulin } \\
\hline II $\left\{\begin{array}{l}\text { A. B. } \\
\text { E. T. }\end{array}\right.$ & $\begin{array}{l}0.389 \\
0.392\end{array}$ & $\begin{array}{l}0.864 \\
0.871\end{array}$ & $\begin{array}{l}1.7 \\
1.9\end{array}$ & $\begin{array}{l}2.5 \\
2.2\end{array}$ & $\begin{array}{r}12.8 \\
3.9\end{array}$ & $\begin{array}{l}3.2 \\
5.3\end{array}$ & $\begin{array}{l}0.054 \\
0.176\end{array}$ & $\begin{array}{l}0.219 \\
0.132\end{array}$ \\
\hline III-S. L. & 0.173 & 0.384 & 2.5 & 1.7 & 3.6 & 3.3 & 0.196 & 0.213 \\
\hline
\end{tabular}

* Serum concentration $X$ plasma volume.

+ See text: $T_{A}=$ serum concentration $X$ plasma volume $\div 0.45$.

$\ddagger$ Equation (3). 
was the case in these children; mathematical analysis of such a system reveals that at no time will uniform specific activities exist throughout the system (15). Under these circumstances, plasma disappearance curves cannot be used directly for estimation of the half-life or the volume of distribution of a body pool of endogenous protein (15).

These findings, however, do not militate against the assumption that radio-iodinated albumin is a suitable tracer for endogenous albumin. While the body pool of albumin in these children was presumed to be in a steady state in that the pool contained constant amounts of albumin with a given anatomical distribution in the body, it is almost unnecessary to state that the pool was in a continuous state of flux; albumin was lost from the pool by catabolism or excretion and was constantly replaced by newly synthesized albumin molecules. As will be shown later, intravenously administered iodoalbumin behaves as does newly synthesized albumin.

B. Calculation of rates of catabolism, urinary loss and synthesis of albumin: It should be carefully noted that, in the calculations which follow, several assumptions were made: 1) Radio-iodinated albumin is a suitable tracer for native albumin under the conditions of these studies, that in every way it behaves as does native albumin and is handled by the body as is native albumin; 2) nonprotein radio-iodide appearing in the urine is derived from catabolized albumin, i.e., the iodoalbumin is not simply deiodinated, but the molecule is catabolized in a manner analogous to the catabolism of native albumin; 3 ) the patient was in a steady state with respect to total circulating albumin and total body albumin.

That the patients could be considered to be in a steady state with respect to the amount of albu$\min$ in the body and in the circulation during the time period of this study was indicated by the following: 1) The maximum variation in serum albumin concentration as determined immunochemically throughout the study was \pm 10 per cent; 2 ) the plasma volumes at the beginning of the study as estimated with iodoalbumin agreed reasonably well with those determined at the end of the study period using iodo- $\gamma$-globulin (Table II) ; 3 ) the maximum weight gain over this period was 1.2 kilograms in the case of S. L., 0.1 and 2.7 kilograms for D. W. and $\mathrm{K}$. S. The weight gain in these children was presumably due to accumulation of edema and ascitic fluids which have an exceedingly low protein concentration (2). The maximum weight gain in the remaining children was 0.1 to 1.1 kilograms.

The cumulative urinary excretion of radioiodinated albumin and of nonprotein radio-iodide in these patients is plotted in Figures 2 and 3. Correcting for the loss of iodoalbumin from the system because of blood sampling, 2 per cent to 3 per cent of the total dose, the estimated fraction of the total dose represented by urinary loss of iodoalbumin is charted in Table IIA.

If one assumed that albumin, when synthesized, enters the vascular ${ }^{3}$ compartment before being distributed generally to the interstitial fluid, then it can be shown that the total albumin synthesized per unit time, $A_{B}$, can be obtained from the following expression:

$$
\frac{A_{s}}{A_{e}}=\frac{A_{s}{ }^{*}}{A^{*}} \quad \text { or } \quad A_{B}=\frac{A_{e}}{A^{*} / A_{s}{ }^{*}}=\frac{A_{e}}{A_{f}{ }^{*}}
$$

where $A_{e}$ is the amount of endogenous albumin lost in the urine per unit time, $A_{B}{ }^{*}$ is the total dose of radio-iodinated albumin, $A^{*}$ is the amount of radio-iodinated albumin lost in the urine after an infinite time period, and $A_{f} *$ is the fraction of total dose of labelled albumin lost in the urine as labelled albumin.

The amount of native albumin appearing in the urine, $A_{e}$, was estimated immunochemically and the results appear in Table IIA. The amount of albumin synthesized per day was then calculated from Equation 1 and charted in Table IIA. Assuming that the loss of albumin from the body is due either to catabolism or urinary excretion, the amount of albumin catabolized per day, $A_{c}$, was calculated :

$$
A_{0}=A_{s}-A_{e}
$$

It will be noted that the amount of albumin synthesized per day as calculated for these chil-

8 The bulk of evidence appears to indicate the liver as the source of albumin; it would then appear that this assumption is not unreasonable. Even assuming for a moment that the protein in question was synthesized and passed into the circulation via the lymphatics, the protein is transported to the circulation before passing into the interstitial fluids in general. The latter would probably be more to the point for $\gamma$-globulin, since this protein appears to be synthesized in the plasma cells of lymph nodes $(16,17)$ in addition to other sites $(18)$. 


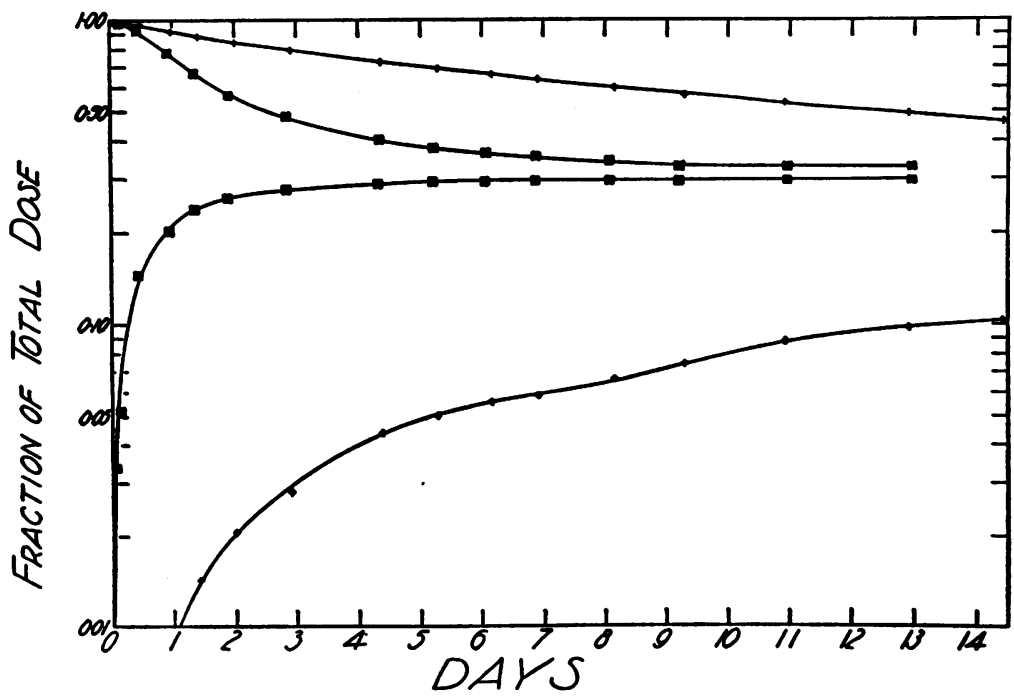

Fig. 2. The Cumulative Urinary Excretion of Radio-Iodinated Albumin (Curves Ascending from Thme Zero) and 1.00 Minus the Cumulative Urinary Excretion of Nonprotein Radio-Iodide of a Patient with Full-Blown Nephrotic Syndrome Compared with That of the Patient Who Recovered from This Disease (Ordinates Are LogaRITHMIC)
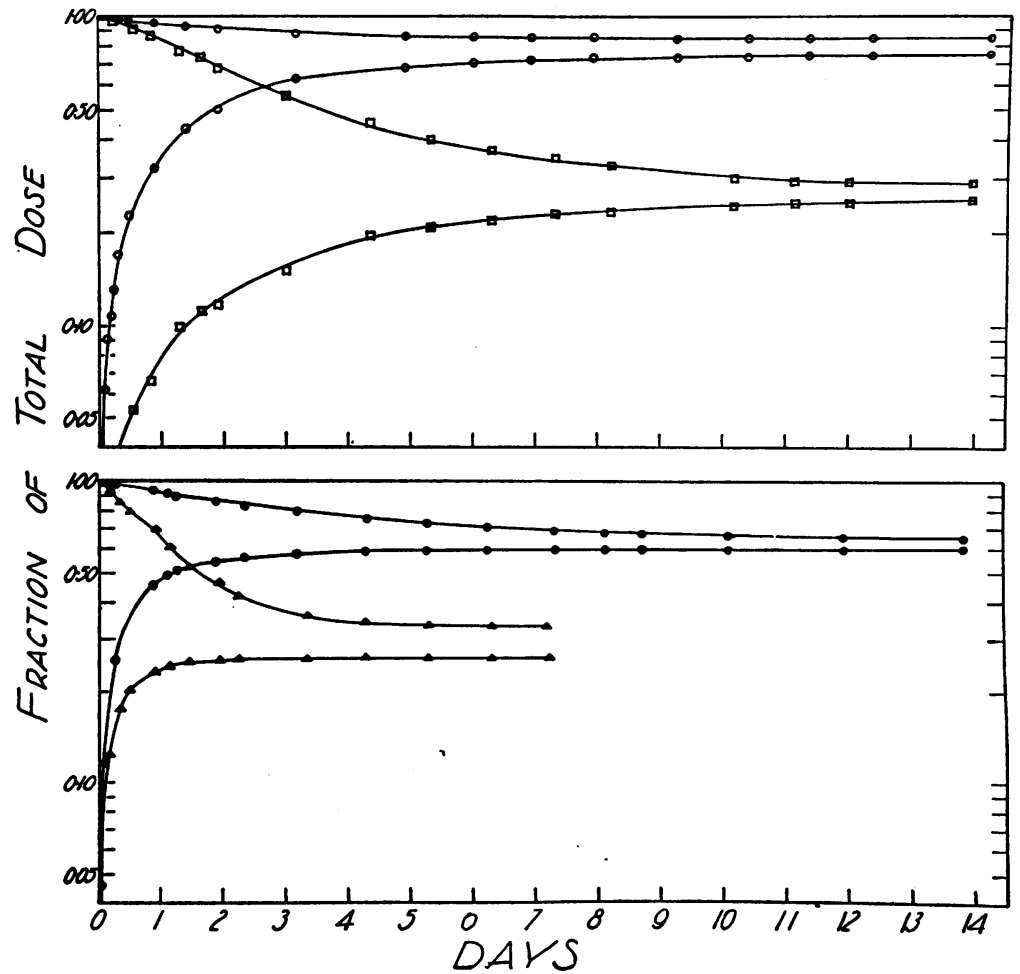

Fig. 3. Thr Cumulative Urinary Excretion of Radio-Iodinated Albumin (Curves Ascrnding froy Time Zero) and 1.00 Minus the Cumulative Urinary Excretion of Nonprotern Radio-Iodide of Two Patients of Group II (Upper Chart) Compared with That of Two Patients of Group III (Lower Chart) (Orpinates Are Logarithmic) 
dren is in the upper limits of the normal range (14).

C. Crude turnover rates of body albumin due to catabolism and urinary loss: If the albumin in the vascular compartment represents about 45 per cent of the total body albumin, $T_{\boldsymbol{A}}(13,14,19)$, the half-time of turnover of body albumin due to catabolism, $t_{c} \frac{1}{2}$, and urinary loss, $t_{e} \frac{1}{2}$, can be calculated (Table IIIA) :

$$
t_{c} \frac{1}{2}=\frac{T_{A}}{A_{c} / 0.693} \text { and } t_{e} \frac{1}{2}=\frac{T_{A}}{A_{e} / 0.693}
$$

If $t_{t} \frac{1}{2}$ is the half-life for total body albumin, then:

$$
t_{t} \frac{1}{2}=\frac{T_{A}}{\left(A_{c}+A_{e}\right) / 0.693}=\frac{t_{c} \frac{1}{2} \cdot t_{e} \frac{1}{2}}{t_{c} \frac{1}{2}+t_{e} \frac{1}{2}}
$$

The fractional rate of catabolism of albumin is the fraction of total body albumin that is catabolized per unit time, or $A_{c} / T_{\Delta}$. Similarly, that fraction of total body albumin lost in the urine per unit time is the fractional rate of urinary loss. These fractional rates are tabulated in Table IIIA.

It would appear that the use of an extravascular albumin of 55 per cent of the total body albumin was not in serious error $(+5$ per cent) in patient R.S.B., as indicated by the extrapolation in Figure 1. This figure, 55 per cent, would represent an upper limit for extravascular albumin for the children of Group II $(2,19)$. Based on albumin determinations in an earlier series of 20 edematous children with active nephrotic syn- drome, it was found, as shown above, that extravascular albumin in patients of Group III constituted about 30 per cent of the total body albumin. Using the figure of 55 per cent, the total body albumin of the children of Group III was probably overestimated; the fractional rates of catabolism and urinary loss for these children, therefore, were actually greater than indicated.

It would appear from the data in Table II that hypoalbuminemia in the patients of Group II could be on a basis of massive albuminuria (patient E.T.) or a markedly increased fractional rate of albumin catabolism (patient A.B.), although elements of increased catabolism and urinary loss were apparent in both patients. The markedly severe hypoalbuminemia seen in the children with ascites and anasarca, however, was apparently the result of combination of both severe albuminuria and greatly increased fractional rate of catabolism of albumin.

It is obvious at once that, without accurate figures for extravascular albumin and total body albumin, these calculations are only approximate, but the significance of even these crude estimations is apparent.

\section{Studies with Radio-iodinated Human $\gamma$-Glob- ulin}

A. The disappearance of iodinated $\gamma$-globulin from the circulation after intravenous injection:

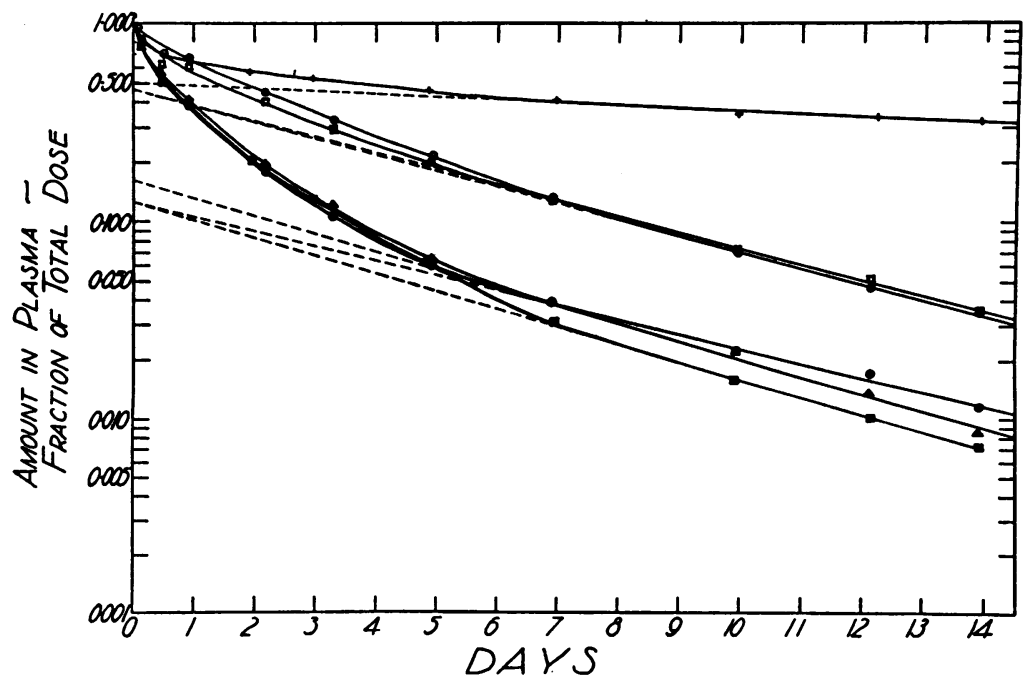

Fig. 4. The Disappearance of Iodinated $\boldsymbol{\gamma}$-Globulin from the Circulation after Intravenous Injection (Ordinates Are Logarithmic) 

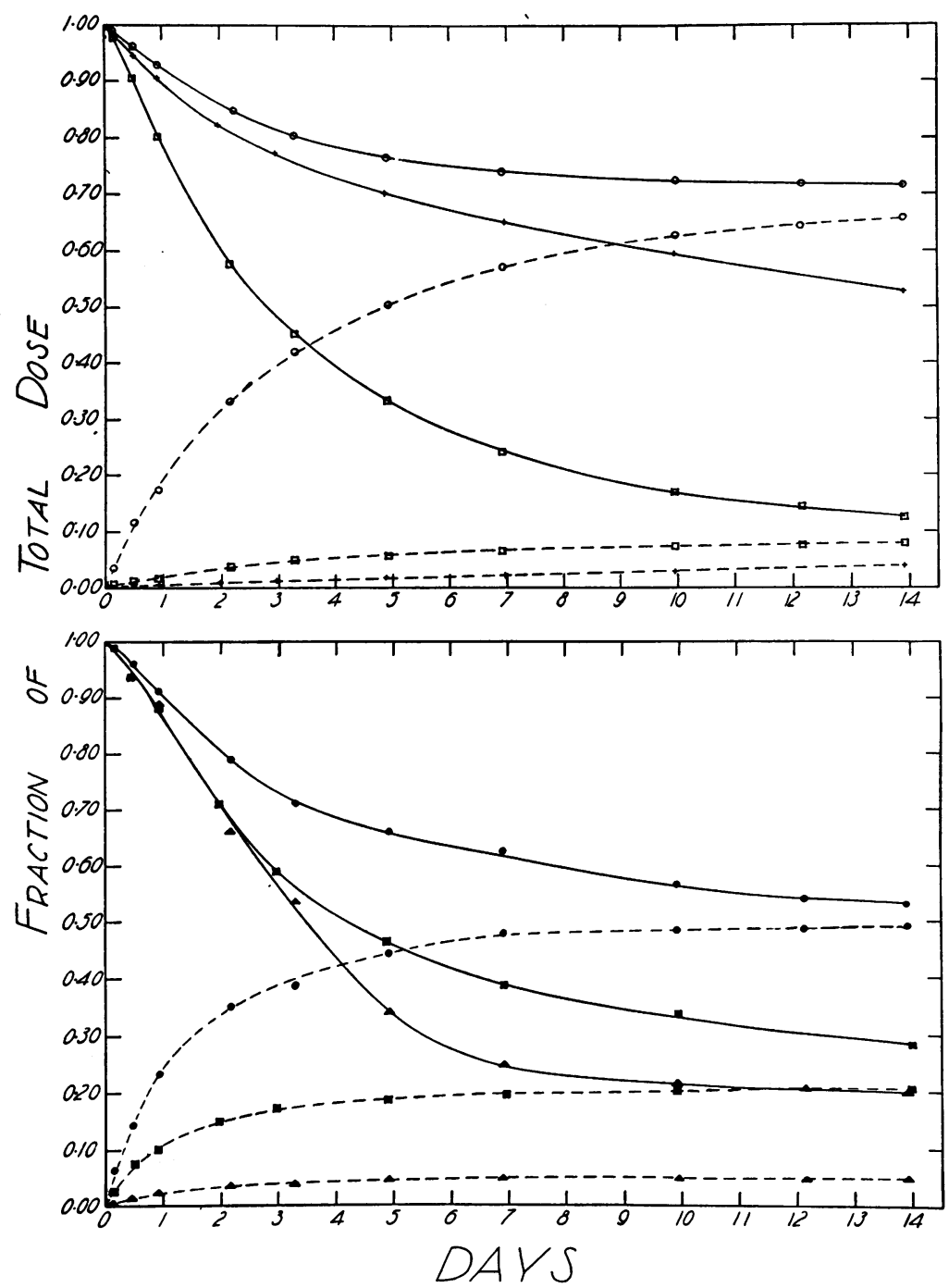

Fig. 5. The Cumulative Urinary Excretion of Radio-Iodinated $\gamma$-Globulin (Dashed Lines) and 1.00 Minus the Cumulative Urinary Excretion of Nonprotein Radio-Iodine (Solid Lines) of the Patients of Groups I and II (Upper Chart) Compared with Those of the Patients of Group III (Lower Chart)

All six children were given radio-iodinated human $\gamma$-globulin intravenously, and the disappearance of this labelled protein from the circulation is shown in Figure 4. Estimation of the half-life of the protein in each patient by graphic analysis resulted in the values shown in Table IIIB; the half-life values appeared to be within normal limits for patient R.S.B., but markedly shortened for the children of Group II and III.

The apparent volume of distribution estimated by extrapolation to zero time (Figure 4) appeared within the normal range for Groups I and II, but in the case of Group III, the extravascular volume of distribution appeared to be 5 to 6 times the plasma volume even after "correction" for possible variations in catabolism (14). Examination of edema fluids, after the logarithmic phase of disappearance of labelled protein from the plasma had been attained in the children with anasarca and ascites, revealed that the specific activity of the $\gamma$-globulin in these fluids was some 8 times that of the serum. As in the case of iodinated albumin, this factor apparently would: 1) Increase the half-life of iodinated $\gamma$-globulin in the 
circulation through a feedback; 2 ) indicate a much larger volume of distribution for iodinated $\gamma$-globulin than is actually the situation for native $\gamma$-globulin in these patients.

The biological half-life of this preparation of radio-iodinated $\gamma$-globulin in three normal children was 17 to 22 days.

B. Rates of catabolism, urinary loss and synthesis of $\gamma$-globulin: The same assumptions which were necessary for the albumin calculations were applied to the study of $\gamma$-globulin. The cumulative urinary excretion of radio-iodinated $\gamma$-globulin and of nonprotein radio-iodide for these children are shown in Figure 5; it is to be noted that both coordinates are linear simply to indicate how these losses appear on this type plot instead of a semilogarithmic plot.

Calculations based on the same considerations of urinary losses as detailed for radio-iodinated albumin resulted in the values for catabolized and synthesized $\gamma$-globulin indicated in Table IIB. It would appear from the data that in the nephrotic syndrome, synthesis of $\gamma$-globulin may be normal or somewhat accelerated.

C. Crude turnover rates of total $\gamma$-globulin due to catabolism and urinary loss: Using the same arguments as for iodinated albumin, the halftimes of turnover of total body $\gamma$-globulin attributable to catabolism and urinary loss were estimated, as well as the corresponding fractional rates of turnover (Table IIIB). It would appear that in one patient of Group II and two patients of Group III, catabolism was of greater influence in keeping the patient in a hypogammaglobulinemic state than was urinary loss; in one patient of Group II, E. T., the urinary loss of $\gamma$-globulin appeared to exert the greater influence, and in S. L., both urinary loss and catabolism were of equal influence.

\section{Studies with Radio-iodinated Iron-binding Globulin}

Three patients were given radio-iodinated human iron-binding globulin intravenously and the plasma disappearance studied; these patients were the two children of Group II and one child of Group III, S. L., The rates of catabolism, synthesis and urinary loss of iron-binding globulin and the turnover rates of this protein due to ca- tabolism and urinary loss were calculated and are charted in Tables IIC and IIIC. The biological half-life for this radio-iodinated iron-binding globulin preparation in a normal child was 12 days.

\section{DISCUSSION}

It is apparent that in children with the nephrotic syndrome, hypoproteinemia is accompanied by a reduced plasma protein pool. For adequate interpretation of the data, it is essential to know whether a reduction in the plasma protein pool occurred as a result of an increased fractional rate of catabolism or whether body requirements demanded the catabolism of a certain minimum amount of plasma protein. In the latter instance, a reduced plasma protein pool resulting from other causes, such as urinary loss, would give rise to an increased fractional rate of catabolism.

Severe reduction in the total body pool of plasma protein in dogs by plasmapheresis $(20,21)$ and in mice by chronic bleeding (20), did not increase the fractional rate of catabolism of homologous plasma albumin. Similarly, the extreme or complete reduction in the body pool of a single plasma protein due to failure in synthesis, such as in congenital agammaglobulinemia (22) or congenital afibrinogenemia (23), does not result in any increase in the fractional rate of catabolism of that protein. In addition, it will be noted that in patient $\mathrm{E}$. T., despite a marked reduction in total body albumin and $\gamma$-globulin, the fractional rate of catabolism of these proteins was not markedly increased. Available evidence indicates that the increased fractional rate of catabolism of plasma protein reported here was not secondary to a reduced plasma protein pool.

In the steady state, the rate of albumin synthesis must equal the rate of loss of albumin from the total body pool. It would appear from the data presented that hypoalbuminemia in children with the nephrotic syndrome is due to an increase in the fractional rate of loss of albumin from the body pool of greater magnitude than any increase in the rate of synthesis, and that this increase in turnover of total body albumin may be the result of a combination of two factors: 1) An increase in the fractional rate of catabolism of albumin; and 2) albuminuria. Moderate hypoalbuminemia, such as that seen in the two children without mani- 
fest ascites but with minimal edema, apparently can be due either to: 1) A relatively severe albuminuria with a moderate increase in the fractional rate of albumin catabolism; or 2) a greatly increased fractional rate of catabolism of albumin in association with but a relatively moderate degree of albuminuria. In children with ascites and anasarca, however, the fractional rate of albumin catabolism and the renal loss of albumin are both greatly increased. In the child who had recovered from the nephrotic syndrome, but who still had a mild proteinuria, the rate of albumin catabolism was apparently within normal limits.

The hypogammaglobulinemia found in this disease can similarly be explained by an increase in $\gamma$-globulin turnover due to an increase in the fractional rate of catabolism of $\gamma$-globulin and by losses of $\gamma$-globulin from the circulation through the renal glomerulus. Thus, almost all of the children of Groups II and III showed increased fractional rates of catabolism; in one child of Group II (E. T.), the increase in turnover of body $\gamma$-globulin could be attributed to renal loss rather than to any increase in catabolism.

The deficiency in circulating iron-binding globulin seen in children with the nephrotic syndrome (24) apparently is attributable to the same factors found for $\gamma$-globulin and albumin; viz., renal loss and an increase in the fractional rate of catabolism of this protein.

The rates of synthesis of albumin and ironbinding globulin in these children, in grams per unit time, were found to be at the upper limits of the normal range. While the rates of synthesis of $\gamma$-globulin also were generally found to be within normal limits, in one child the rate of synthesis was definitely above normal. Certainly, the rates of synthesis determined are somewhat lower than the 2.5 to 5 -fold increase in plasma protein synthesis suggested by others $(1,25)$. This is in accord with the finding that in animals kept on diets normal in protein content and who have been severely depleted of plasma protein by plasmapheresis or by chronic bleeding, the rate of synthesis of albumin was the same as that in normal controls (20).

Using $\mathrm{S}^{85}$-methionine (25) and $\mathrm{N}^{15}$-glycine (26), other investigators have found an increased incorporation of these labels into new plasma protein in the nephrotic syndrome; this has been in- terpreted as indicating a greatly accelerated rate of plasma protein synthesis in this disease. It has been indicated in this report, however, that the turnover rates of the plasma proteins studied may be greatly increased during the nephrotic state and that the concentrations of these proteins in the plasma were much lower than normal; under these circumstances, and especially in the presence of a reduced amino acid pool (27), the rate of label incorporation as measured by the rapid increase in specific activity need not necessarily reflect an increased rate of synthesis of these proteins in terms of grams per day.

In a study of protein and carbohydrate metabolism in nephrotoxic nephritis induced in rats, Drabkin and Marsh (28) have just reported a similar increase in incorporation of $\mathrm{C}^{14}$ in tissue proteins as well. They concluded that an increased turnover of body protein occurred in the nephrotic rat. They also concluded that the metabolic adjustments found in the rat were related to proteinuria in that the metabolic pathways were channeled into increased protein synthesis in an attempt to adjust to renal excretion of protein (29). In several of the children reported here, the fractional rate of catabolism, however, was of greater influence on the turnover of plasma protein than was the fractional rate of renal excretion, and protein synthesis was not greatly increased in any.

During the course of this report, the reader has been subjected to a seemingly inordinate series of assumptions which may be true only within certain limits. For simplification, in the presentation of the results of this study, it was assumed that the radio-iodinated plasma proteins used in this investigation were satisfactory for studying the catabolism of the native proteins. This was done with full realization that this assumption may not have been strictly true. In children with congenital agammaglobulinemia, for example, it has been found that the rate of catabolism of radioiodinated $\gamma$-globulin is considerably faster than that of unlabelled $\gamma$-globulin (22). To test this possibility, Table IV was constructed assuming that the catabolized fraction of the native albumin had been overestimated by a factor of 2 ; it can be seen that the general conclusions reached need not be radically changed. If, by unusual circumstance, the iodinated albumin had been catabolized 
TABLE IV

Rate of turnover of endogenous albumin if the fraction of albumin catabolized had been overestimated by a factor of 2

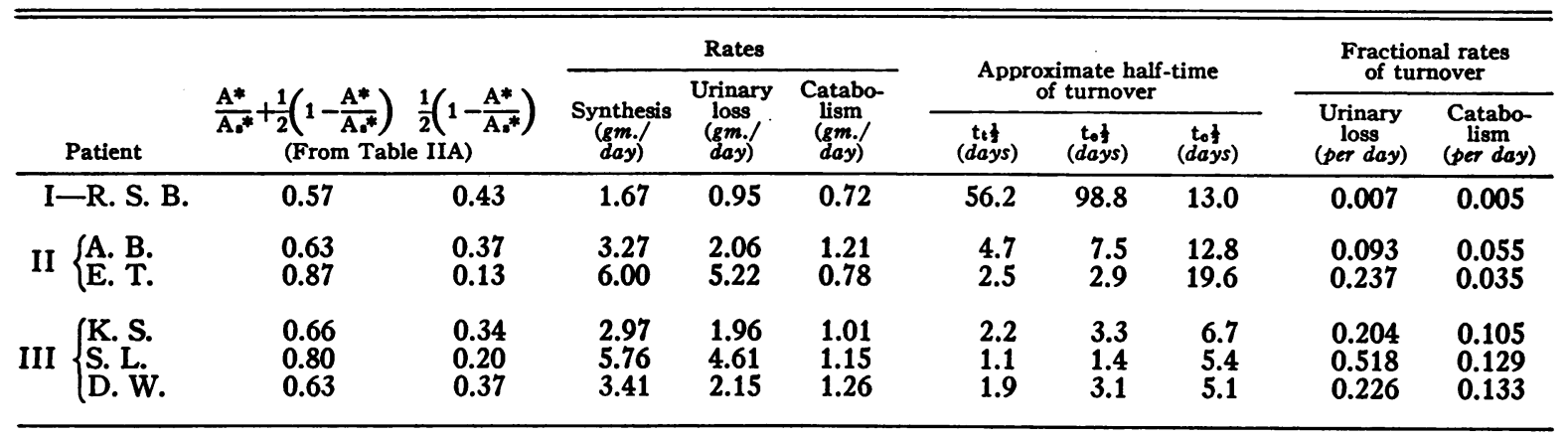

more slowly than the native albumin, the fractional catabolic rate for the iodinated albumin would have had to fall to less than $1 / 5$ th of its normal rate to alter the conclusions.

\section{SUM MARY}

Six children in various phases of the nephrotic syndrome were given tracer doses of radio-iodinated human plasma albumin and radio-iodinated human $\gamma$-globulin intravenously in sequence. Three of these children were then given intravenous injections of radio-iodinated human ironbinding globulin. The disappearance of specific radio-iodinated plasma protein from the circulation and its cumulative appearance in the urine were studied; the urinary excretion of nonprotein radio-iodide was also investigated. Unlabelled albumin, $\gamma$-globulin, and iron-binding globulin in serum and urine, and in several instances in edema fluid, were estimated immunochemically and the renal clearances of these proteins determined.

Calculations indicated that the half-time of turnover for native plasma albumin could not be estimated from the plasma disappearance curves of the radio-iodinated analogue in the edematous patient; in the phase of exponential disappearance from the circulation, the specific activity of the given protein in the extravascular fluid was found to be 8 to 30 times that in the plasma. The large apparent volume of distribution obtained by extrapolation of the exponential portion of these curves is, at least in part, a reflection of this difference in specific activities and while the extrapolation indicates the volume of distribution of the radioiodinated plasma protein during this phase, it does not measure the volume of distribution of the native protein in the steady state.
The deficiencies of albumin, $\gamma$-globulin and ironbinding globulin seen in the plasma of children with the nephrotic syndrome are due to an increased fractional rate of catabolism of these proteins in association with renal losses. Moderate hypoalbuminemia without apparent ascites but with minimal edema may be associated with either a greatly increased fractional rate of catabolism of albumin or a severe degree of albuminuria; severe hypoalbuminemia with ascites and anasarca is the result of both greatly increased catabolism and severe albuminuria occurring simultaneously.

The rates of synthesis of albumin, $\gamma$-globulin and iron-binding globulin in these children were at the upper limits of the normal range except that in one instance, an increased rate of $\gamma$-globulin synthesis was found.

\section{ACKNOWLEDGMENT}

The authors are grateful for this opportunity to acknowledge their indebtedness to Dr. Charles Lewallen, Dr. Walter L. Hughes, Jr., Dr. James S. Robertson, and Dr. Arthur K. Solomon for their advice and encouragement, and for their critical review of this manuscript.

\section{APPENDIX}

The system considered in these children for the calculation of the rate of synthesis of endogenous plasma protein is a simple one in which the endogenous or carrier protein enters and leaves the system at a rate, $A_{2}$, and is excreted from the system at a rate, $A_{0}$. If $R^{*}$ is the radioactivity in the system at any given time, $R^{*}$ is a function of time:

$$
R^{*}=\Phi(t)
$$

and has a rate of change:

$$
\frac{d R^{*}}{d t}=-\frac{d \Phi(t)}{d t}
$$

Assuming the tracer behaves like the carrier:

$$
\frac{A_{0}}{A_{.}} \frac{d R^{*}}{d t}=-\frac{A_{0}}{A_{1}} \frac{d \Phi(t)}{d t}
$$


Solving for the amount, $A^{*}$, of tracer excreted from time 0 to $\mathrm{T}$ :

$$
\begin{aligned}
\int_{0}^{T} \frac{A_{0}}{A_{s}} \frac{d R^{*}}{d t} & =\int_{0}^{T}-\frac{A_{0}}{A_{s}} \frac{d \Phi(t)}{d t} \\
A^{*} & \left.=-\frac{A_{0}}{A_{s}} \frac{d \Phi(t)}{d t}\right]_{0}^{T}
\end{aligned}
$$

If at $t=0, \Phi(t)=A_{s}{ }^{*}$, where $A_{B}{ }^{*}$ is the total amount of radioactivity injected and at $t=\infty, \Phi(t)=0$, then

or

$$
A^{*}=\frac{A_{0}}{A_{8}} A_{8}^{*}
$$

$$
A_{b}=\frac{A_{0}}{A^{*} / A_{*}^{*}}
$$

\section{REFERENCES}

1. Barnett, H. L., Forman, C. W., and Lauson, H. D., The nephrotic syndrome in children in Advances in Pediatrics, Levine, S. Z., Ed., Chicago, Yearbook Publishers, Inc., 1952, Chap. V, p. 53.

2. Gitlin, D., and Janeway, C. A., An immunochemical study of the albumins of serum, urine, ascitic fluid and edema fluid in the nephrotic syndrome. J. Clin. Invest., 1952, 31, 223.

3. Bradley, S. E., and Tyson, C. J., The "nephrotic syndrome." New England J. Med., 1948, 238, 260.

4. Eder, H. A., Lauson, H. D., Chinard, F. P., Greif, R. L., Cotzias, G. C., and Van Slyke, D. D., A study of the mechanisms of edema formation in patients with the nephrotic syndrome. J. Clin. Invest., 1954, 33, 636.

5. Melnick, D., and Cowgill, G. R., The problem of hypoproteinemia. Yale J. Biol. \& Med., 1937, 10, 49.

6. Peters, J. P., Bruckman, F. S., Eisenman, A. J., Hald, P. N., and Wakeman, A. M., The plasma proteins in relation to blood hydration. VI. Serum proteins in nephritic edema. J. Clin. Invest., 1931, 10, 941.

7. Gitlin, D., Use of ultraviolet absorption spectroscopy in the quantitative precipitin reaction. J. Immunol., 1949, 62, 437.

8. Oncley, J. L., Melin, M., Richert, D. A., Cameron, J. W., and Gross, P. M., Jr., The separation of the antibodies, isoagglutinins, prothrombin, plasminogen, and $\beta_{1}$-lipoprotein into subfractions of human plasma. J. Am. Chem. Soc., 1949, 71, 541.

9. Koechlin, B. A., Preparation and properties of serum and plasma proteins. XXVIII. The $\beta_{1}$-metal-combining protein of human plasma. J. Am. Chem. Soc., 1952, 74, 2649.

10. Gitlin, D., Landing, B. H., and Whipple, A., The localization of homologous plasma proteins in the tissues of young human beings as demonstrated with fluorescent antibodies. J. Exper. Med., 1953, 97, 163.

11. Pressman, D., and Eisen, H. N., The zone of localization of antibodies. V. An attempt to saturate antibody-binding sites in mouse kidney. J. Immunol., 1950, 64, 273.
12. Latta, H., Experimental hypersensitivity in the rabbit. Blood and tissue concentrations of foreign proteins labeled with radioactive iodine and injected intravenously. J. Immunol., 1951, 66, 635.

13. Sterling, K., The turnover rate of serum albumin in man as measured by $\mathrm{I}^{131}$-tagged albumin. J. Clin. Invest., 1951, 30, 1228.

14. Berson, S. A., Yalow, R. S., Schreiber, S. S., and Post, J., Tracer experiments with $I^{181}$ labeled human serum albumin: distribution and degradation studies. J. Clin. Invest., 1953, 32, 746.

15. Robertson, J. S., Discussion. Fourth Annual Conference on the Nephrotic Syndrome. Metcoff, J., Ed., New York, National Nephrosis Foundation, 1952.

16. Coons, A. H., Leduc, E. H., and Connolly, J. M., Immunohistochemical studies of antibody response in the rabbit. Federation Proc., 1953, 12, 439.

17. Craig, J. M., Gitlin, D., and Jewett, T. C., The response of lymph nodes of normal and congenitally agammaglobulinemic children to antigenic stimulation. Am. J. Dis. Child., 1954, 88, 626.

18. Ranney, H. M., and London, I. M., Antibody formation in surviving tissues. Federation Proc., 1951, 10, 562.

19. Gitlin, D., and Janeway, C. A., Studies on the plasma proteins in the interstitial fluid of muscle. Science, 1954, 120, 461.

20. Gitlin, D., Hughes, W. L., Jr., and Janeway, C. A., Unpublished data.

21. Yuile, C. L., Lucas, F. V., Neubecker, R. D., and Whipple, G. H., Reduction of extravascular-extracellular proteins in protein-depleted dogs. Federation Proc., 1955, 14, 424.

22. Janeway, C. A., Gitlin, D., and Apt, L., Unpublished data.

23. Gitlin, D., and Borges, W. H., Studies on the metabolism of fibrinogen in two patients with congenital afibrinogenemia. Blood, 1953, 8, 679.

24. Cartwright, G. E., Gubler, C. J., and Wintrobe, M. M., Studies on copper metabolism. XI. Copper and iron metabolism in the nephrotic syndrome. $\mathrm{J}$. Clin. Invest., 1954, 33, 685 .

25. Kelley, V. C., Ziegler, M. R., Doeden, D., and Mcquarrie, I., Labeled methionine as an indicator of protein formation in children with lipoid nephrosis. Proc. Soc. Exper. Biol. \& Med., 1950, 75, 153.

26. Spector, W. G., Labelled glycine in the nephrotic syndrome. Clin. Sc., 1954, 13, 1.

27. Farr, L. E., and MacFadyen, D. A., Hypoaminoacidemia in children with nephrotic crises. Am. J. Dis. Child., 1940, 59, 782.

28. Drabkin, D. L., and Marsh, J. B., Metabolic channeling in experimental nephrosis. I. Protein and carbohydrate metabolism. J. Biol. Chem., 1955, 212, 623.

29. Marsh, J. B., and Drabkin, D. L., Metabolic channeling in experimental nephrosis. II. Lipide metabolism. J. Biol. Chem., 1955, 212, 633. 